\title{
Occurrence of Porphyromonas gingivalis fimA type II and prtC genotype among periodontitis patients
}

\author{
Mahalakshmi Krishnan ${ }^{1,2^{*}}$, Padma Krishnan', Subashini Natarajan ${ }^{3}$ \\ From First International Science Symposium on HIV and Infectious Diseases (HIV SCIENCE 2012) \\ Chennai, India. 20-22 January 2012
}

\section{Background}

Porphyromonas gingivalis fimbriae are classified into six genotypes (types I-V and Ib). Among them, occurrence of fimA type II genotype is more predominant in periodontitis patients. Similarly collagenase encoded by prtC gene is a potential virulence factor expressed by $P$. gingivalis strains associated with periodontal disease. The study was opted to detect the presence of $P$. gingivalis fimA type II and prtC genotypes in periodontitis patients.

\section{Methods}

Subgingival plaque samples collected from 128 chronic periodontitis (ChP) and 72 aggressive periodontitis (AgP) patients were subjected to PCR to screen for the presence of fimA type II and prtC gene of $P$. gingivalis. Chi-square test was employed to compare the prevalence of the genotypes.

\section{Results}

The prevalence of $P$. gingivalis fimA type II genotype among ChP, AgP and health was $50.5 \%, 45.3 \%$ and $13.60 \%$, respectively. While, prevalence of $P$. gingivalis prtC genotype among ChP, AgP and health was $49.5 \%$, $45.3 \%$ and $9.10 \%$ respectively. $P$. gingivalis type II fimA + prtC + genotype were present in $28.9 \%$ of ChP, $33.3 \%$ of AgP patients and $4.5 \%$ of healthy subjects. Patients positive for both the genes showed probing depth of $\geq 7 \mathrm{~mm}$. Significant difference was observed between periodontitis and healthy subjects for all the three genotypes $(P=0.001)$.

\footnotetext{
* Correspondence: kmag_1985@yahoo.co.in

'Department of Microbiology, Dr. ALM PGIBMS, University of Madras,

Chennai, India

Full list of author information is available at the end of the article
}

\section{Conclusion}

The results show that $P$. gingivalis fim $A$ type II and $p r t C$ genotypes are equally associated with chronic and aggressive periodontitis. The predominance of $P$. gingivalis fim $A$ type II+ / prtC+ genotype in teeth with deep pockets or serious attachment loss, suggest their role in periodontal destruction.

\section{Author details \\ ${ }^{1}$ Department of Microbiology, Dr. ALM PGIBMS, University of Madras, Chennai, India. ${ }^{2}$ Department of Microbiology, Sree Balaji Dental College and Hospital, Chennai, India. ${ }^{3}$ Department of Periodontics and Implantology, Tamilnadu Government Dental College and Hospital, Chennai, India.}

Published: 4 May 2012

doi:10.1186/1471-2334-12-S1-P22

Cite this article as: Krishnan et al: Occurrence of Porphyromonas gingivalis fimA type II and prtC genotype among periodontitis patients. BMC Infectious Diseases 2012 12(Suppl 1):P22.

Submit your next manuscript to BioMed Central and take full advantage of:

- Convenient online submission

- Thorough peer review

- No space constraints or color figure charges

- Immediate publication on acceptance

- Inclusion in PubMed, CAS, Scopus and Google Scholar

- Research which is freely available for redistribution

Submit your manuscript at www.biomedcentral.com/submit

\section{() Biomed Central}

\section{Biomed Central}

